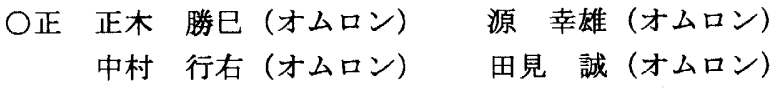

Katsumi Masaki, Yukio Minamoto, Kosuke Nakamura, Makoto Tami OMRON Corporation, KYOTO

In the engineering process from the product project to development and production, It is made to see by every single person's experience and knowhow's using QFD, FMEA, and the parameter design. As a result, the problem is persisting extracted beforehand. Shortening at the development period and a vertical start-up of the production line were achieved.

Key Words : Engineering Process, Quality Function Deployment, Failure Mode and Effects Analysis, Robust Design

1.はじめに

近年の顧客ニーズの多様化、市場のグローバル化、製品 の短寿命化に伴い、製品をタイムリーに市場投入するため の開発供給サイクル（設計開発期間、生産立上げ）の短期 化が求められている。一方、設計プロセスの細分化により 設計者が全体像を見失ったり、モノづくりの現実感を伴わ ない設計者の増加など経験やノウハウ情報の伝承がうまく おこなわれずに、結果として後プロセスで問題が発生し、 練り返し・やり直し業務が増えることから、設計開発期間 が長期化したり生産立上げが進まなかったりということが 多々ある。

\section{2. 源流課題管理}

設計開発期間の短縮や生産の垂直立上げが、「なぜ思い どおりにいかないのか?」と考えると、

(1)プロジェクトの計画機能が弱い

(2)源流課題管理と品質・原価等の完成度評価方法未確立

(3)構想が見える状態にない、関係者に伝わらない

(4)情報共有化が不充分

(5)ナレッジの再活用がない

以上のようなことが挙げられる。

通常、開発設計プロセスが進むと課題の性質が Fig. 1 に 示すように「潜在課題」 $\rightarrow$ 「顕在課題」 $\rightarrow$ 「処理課題」 $\rightarrow$

「解決·完成」へと変わっていき、解決·完成を早い段階で 実現することが、設計開発期間の短縮や生産の垂直立上げ に慗がることになる。

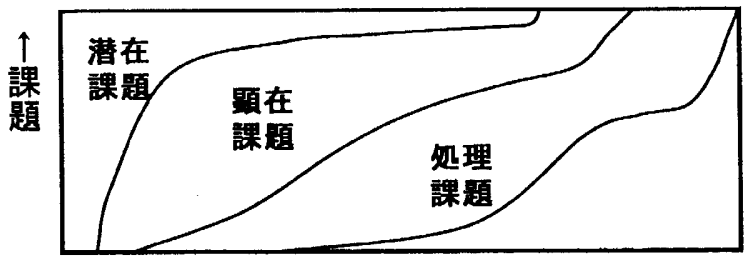

開発プロセス $\rightarrow$

Fig. 1 開発設計プロセスと課題性質変化

そこで、開発設計の源流段階で開発設計プロセス全体を 通しての（潜在）課題を事前徹底抽出（顕在課題化）し、 課題解決策を棈想・方向付け（処理課題化）する。

つまり、開発構想を見えるようにすることで、関係者が 各プロセスでおこなうべき検討アクションを明瞭にして

「全員参画型開発」にしていくことをめざす。
3.取組みポイント

開発設計プロセスにおける課題の性質変化に対応させて、 (1)潜在課題 $\Leftrightarrow$ Q F D (Quality Function Deployment : 品質機能展開）手法による開発設計品質 目標と課題の明確化

(2)顕在課題 $\Leftrightarrow$ F ME A (Failure Mode and Effects Analysis : 故障モードと影響解析) 手法に よる品質・信頼性造り込みと解決方策検討

(3)処理課題 $\Leftrightarrow$ パラメータ設計（Robust Design）手法に よる論理的な思考で、品質とコストの最適 の取組みをおこなった。 化と設計品質から製造品質の一気通貫化

\section{1 QF D (Fig. 2)}

これまでに蓄積されたきた技術情報（製品技術調査依頼 製品改造依頼等) は個々には存在するが、それらを体系だ てて整理し伝えることは充分おこなえていなかった。また 営業担当者、商品企画担当者、商品設計担当者が各々頭の 中に様々な市場情報を持っており、これらの情報が形式知 化されることも充分ではなかった。

そこでQF D 手法を用いて、社内に散在しているお客様 からの要求事項を整理して、要求品質 (Voice of Customer) としてまとめた。それらから商品に求められる機能と品質 を市場要求や対競合商品等の観点で分析し、どの品質要素 が重要であるかを判断し、商品仕様・性能・特性、制約条件 など開発設計品質目標と課題の明確化につなげた。

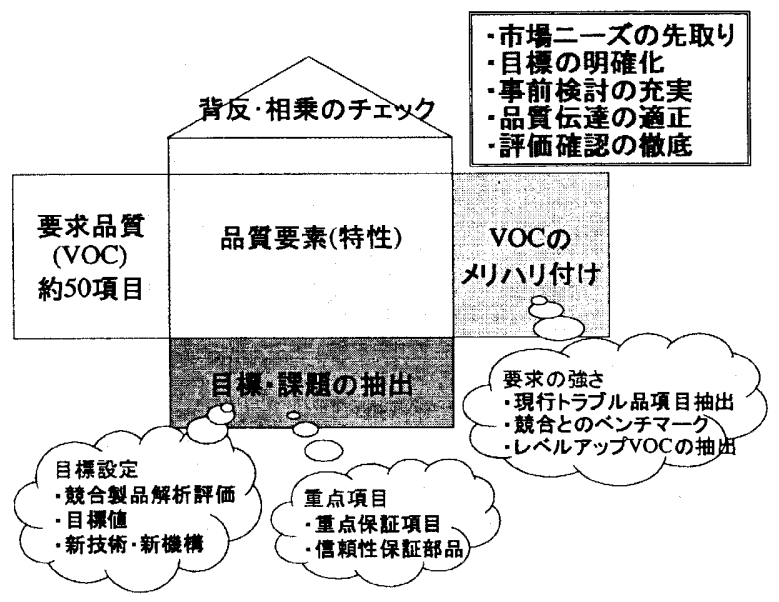

Fig. 2 QFD（品質の家=House of Quality） 
3. 2 F ME A

F MEAは、製品設計、工程設計および設備設計など設 計の不完全さや潜在的な欠陥を見いだすために、構成要素 の故障モードとその上位アイテムへの影響を解析し、設計 改善へ結びつけていくための手法である。

通常は、各設計の段階ごとに Fig. 3のような狙いを持っ て順次展開される。

\begin{tabular}{|c|c|}
\hline 㹈品企画 & $\begin{array}{l}\text { システム・製品機能の潜在的技術課題の } \\
\text { 論理的な検討 }\end{array}$ \\
\hline 製品設計 & $\begin{array}{l}\text { 製品設計要素(機能·性能·部品)の重要 } \\
\text { 技術課題への対策妥当性の検討 }\end{array}$ \\
\hline 工程設計 & $\begin{array}{l}\text { 生産工程課題の予測と重要工程の抽出 } \\
\text { 舷品設計反映と工程設計改並検討 }\end{array}$ \\
\hline 設備設計 & $\begin{array}{l}\text { 製品品賁、作業安全性に関する面から } \\
\text { 設備設計重要部位の改善検討 }\end{array}$ \\
\hline
\end{tabular}

Fig. 3 設計段階ごとのFME A使い分け

各設計を進めながら順次実施すると、問題·課題発見が 先送りとなることが懸念される。したがって製品企画段階 での構想図（ラフスケッチ）から製品（詳細）設計に至る 間のできるだけ早い時期に、どの設計段階で重要技術課題 の解決方策を実施することが最も効率的で確実かを検討す ることが極めて重要となる。

製品構造設計や部品形状・寸法公差設計で解決できるよ うに基本的には進めるが、工程でのバラッキ・変動要素に 関連するものについては、工程能力改善や統計的工程管理 (SPC : Statistical Process Control) を活用し解決する ために工程や設備の仕様に盛込む。

それでも解決できない部分についてのみ、各種管理基準 を明確にし、人系での管理をおこなうことにする。ただし 作業安全に関することについては、人系での管理項目とせ ずに、必ず設備ないし製品設計の中で解決するようにした。

このようなことをおこなうことで、

(1)設計効率の向上に役立つとともに、工程への伝達が重 点的·合理的になる

(2)製品機能と特性の関連が明確となり、重要特性が明確 になり、対策がたて易くなる

(3)文書化により、技術・ノウハウが蓄積される といったメリットがあり、製品立上げ時のトラブルも格段 に減少できた。

\section{3 パラメータ設計}

ここまでで明確になった重要技術課題の解決に対して、 ロバスト設計の考え方（Fig.4）に基づいて、使用環境条件
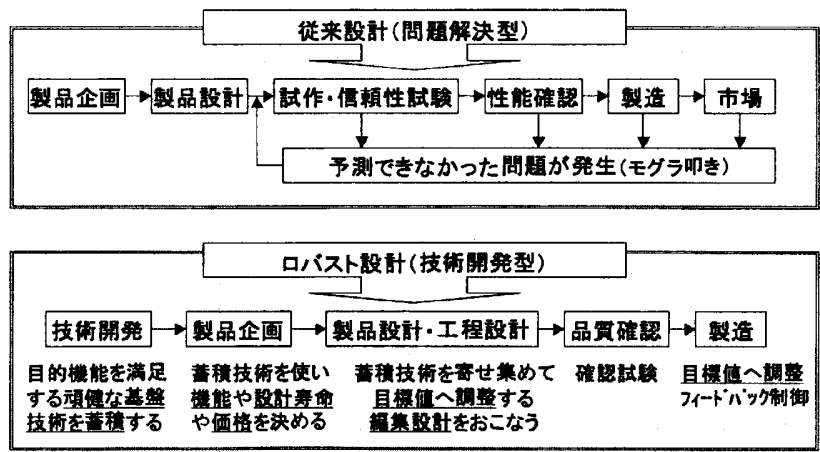

Fig. 4 従来設計とロバスト設計の比較
や劣化などの「ノイズ」に対して、お客様が欲しい「機能」 が安定するような評価をおこなう。

ノイズに対する「バラッキ」を低減することで、品質問 題の「モグラ吅き」による問題解決型開発から、機能性改 善を図る技術開発型体制に移行する。機能とノイズに対す る技術開発をおこなうので、共通的な技術蓄積が短期間に おこなえる。これにより設計開発期間の短縮を図り、生産 化スピードを高めることが可能となった。

4.情報システムによるサポート

製品企画〜開発·設計〜生産に至るエンジニアリングプ ロセスの各フェーズでアウトプットされる、QF DやF M E Aなどの各種データをFig. 5 のような開発・生産統合デ ータベースに保管する。データベースでは、必要に忘じて データの関連付けをおこなう。例えば、設計FME Aにお ける工程での解決課題・方策は工程 F M E Aにリンクされ、 それらが工程品質確認図や作業手順書へリンクされる形に なる。逆に言えば各工程での管理項目から、なぜその項目 を管理しなければならないのか（設計要因）が簡単に分か るようになる。

また、実生産における製品品質管理、プロセス管理、設 備保全管理などの収集データをこのデータベースの特性要 因情報を元に分析をおこなうことで、どのようなフィード バックまたはフィードフォワードをどこに向けてかけるか を判断することができる。

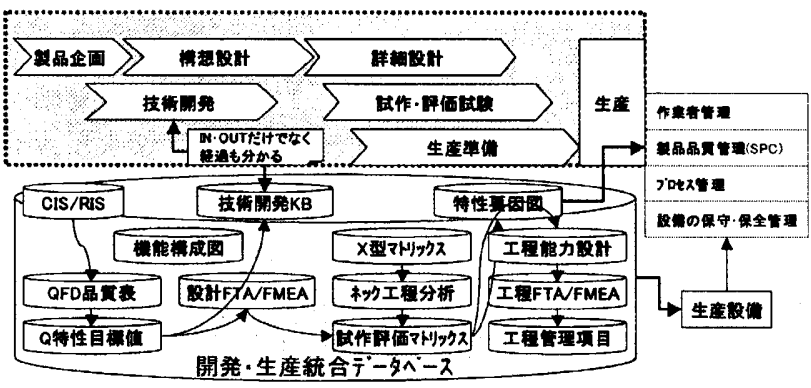

Fig. 5 開発生産統合データベース全体構成

5.まとめ

今回の取組みでは、対象とした製品での設計の繰返し. やり直しを激堿させるとともに、関係者間での方向性や情 報共有が進んだことで、開発工数を大幅に短縮すると共に 生産ラインの垂直立上げの実現にもつながった。

また、この取組みで蓄積したナレッジや技術ノウハウの 次期製品の設計開発への活用も容易となり、大きな効果が 出つつある。

更に今後は、設計開発技術資産を蓄積し、お客さまへの 技術情報提供などへの活用についても検討していく。

参考文献

（1）正木勝巳、吉井実、川田一樹：「メカニカルコンポ 商品群設計・生産プラットフォーム開発」、OMRON TECHINICS Vol.43 No.2 2003 (通巻 146 号)

（2）吉井実：「需要同期生産を目指した開発・生産統合 プラットフォーム」、日本機械学会 2002 年度年 次大会講演論文集 $(\mathrm{V})$

（3）塩見弘、島岡淳、石山敬幸：「FME A、F T A の 活用」（1983）、日科技連出版社 